\title{
Challenges and Opportunities for Higher Education amid the COVID- 19 Pandemic: The Philippine Context
}

\author{
Cathy Mae Toquero ${ }^{1 *}$ \\ ${ }^{1}$ College of Education, Mindanao State University, General Santos City, PHILIPPINES \\ *Corresponding Author: cathymaetoquero@gmail.com \\ Citation: Toquero, C. M. (2020). Challenges and Opportunities for Higher Education amid the COVID-19 Pandemic: The Philippine Context. \\ Pedagogical Research, 5(4), em0063. https://doi.org/10.29333/pr/7947

\begin{abstract}
ARTICLE INFO
Received: 10 Apr. 2020

Accepted: 11 Apr. 2020

ABSTRACT

Covid-19 affected higher educational institutions not just in Wuhan, China where the virus originated but all other higher educational institutions in 188 countries as of April 06, 2020. Educational countermeasures are taken to continue educating the students despite the COVID-19 predicaments. Based on the author's experiences, research, observations in the academe, COVID-19 guidelines, and the need for alternative solutions, this article introduces how higher education is affected and how it can respond to future challenges. This article recommends to educational institutions to produce studies to proliferate and document the impact of the pandemic to the educational system. There is also a greater need for educational institutions to strengthen the practices in the curriculum and make it more responsive to the learning needs of the students even beyond the conventional classrooms.
\end{abstract}

Keywords: COVID-19, higher education, curriculum, online learning, mental health services, environmental health education

\section{INTRODUCTION}

What is COVID-19? COVID-19 stands for coronavirus disease and even referred to as the 2019 novel coronavirus or '2019-nCoV' (Bender, 2020). The COVID-19 virus is linked to Severe Acute Respiratory Syndrome Coronavirus 2 (SARS-CoV) that similarly can be as fatal (Meng, Hua, \& Bian, 2020). This new virus can be transmitted just in minutes through droplets or even touching surface metals or other materials which have been infected from a person who has respiratory problems. Even though the elderly and the very young children are easily affected, nobody is immune to this new infectious disease once it hits the body, so all people are susceptible to its devastating effects (Bender, 2020; Meng, Hua, \& Bian, 2020).

Because of the vulnerability even in school settings, thousands of school closures are implemented the world over due to COVID-19. As of April 06, 2020, UNESCO (2020) reported that there has been 1, 576, 021, 818 affected learners out of $91.3 \%$ total enrolled learners in 188 countries in all levels of learning. Similarly, there were school and university closures that happened during the outbreak of the Severe Acute Respiratory Syndrome or SARS in China in 2003. In Hong Kong for example, there were 1 , 302 schools which closed, 1,000,000 children stayed at home, and 50, 600 teachers faced challenges in using technology to provide education to their students (Fox, 2007).

In the Philippines, due to the 4, 195 confirmed cases as of April 10, 2020 based on the Department of Health (DOH, 2020) online tracker report, the COVID-19 pandemic really causes a massive impact in higher educational institutions. The country immediately opted for online learning. Some teachers recorded and uploaded their lessons online for the students to access and some were even more innovative (Fox, 2007) and used Google Classrooms, WebQuest, and other online sites, but a greater majority of teachers are not prepared to deal with online education. After three days of the national memorandum for alternative delivery, the Commission on Higher Education (CHED) suspended the online form of instruction since there was an increase in the number of the students, including teachers who clamoured against the online mode of learning due to different factors. The truth is, numerous higher education institutions, both private and state colleges and universities in the Philippines are not prepared to implement this online system.

Few research have been done so far in relation to COVID-19 from the medical field and other fields related to health sciences (Abdulamir, \& Hafidh, 2020; Meng, Hua, \& Bian, 2020; Gondauri, Mikautadze, \& Batiashvili, 2020; Holshue et al., 2020; Usak, Masalimova, Cherdymova, \& Shaidullina, 2020). However, very meager research is done in relation to the field of education on how COVID-19 or even SARS affected the educational system (Bao, 2020; Sintema, 2020; Yan, 2020). 
Strengthening the educational planning and health measures in the university can provide the students and the rest of the stakeholders with an opportunity to continue learning while preventing the spread of the virus. Such preventive measures can improve environmental hygiene to mitigate the transmission of the infectious disease (Lee et al, 2003). Hence, this paper has been created to hopefully encourage other educational researchers to also document and produce research evidences on how the present pandemic has changed the working of the educational systems in the entire world. The proliferation of knowledge starts in the educational institutions. Consequently, the educational system, especially higher education, should prioritize literacy for the world to adeptly deal with a future virus outbreak.

\section{RECOMMENDATIONS FOR HIGHER EDUCATION}

Based on the need for improvement in the instructional delivery in the Philippine context, this article presents opportunities for higher education to respond to the educational problems that arise due to the COVID-19 pandemic.

\section{Integrate Environment and Health Courses in the Curriculum}

Higher education institutions should integrate environmental and health courses in the curriculum. It is particularly of utmost importance to make the curriculum as responsive to the needs of the world at the present times. The integration of basic environmental and health courses should be accessible to all students in the university (Türkoglu, 2019) and not just for the science-related majors since everybody deals with environmental and health problems. Learning materials which are focused on environmental literacy can also be developed for utilization in classroom instruction and for training to a wider audience in the society (Türkoglu, 2019).

Environmental science education programs can produce citizens who can be environmentally literate and can exemplify environmental health concerns for social action (Keselman, Levin, Kramer, Matzkin, \& Dutcher, 2011).This is to adapt to the real issues that the world is dealing with and thereby create awareness and improve positive attitudes among the students (Amin, Mahadi, Ibrahim, Yaacob, \& Nasir, 2012; Türkoglu, 2019), strengthen educational health practices, and implement effective environmental education policies. The integration can present barriers to the teachers such as time constraints, pressures of imposed guidelines, and lack of enough knowledge to teach environmental health, among others (Keselman, Levin, Kramer, Matzkin, \& Dutcher, 2011). Nonetheless, environmental health is highly regarded worldwide, especially after having to deal with the global pandemic at the present time. This curriculum endeavor can help address future environmental issues.

\section{Strengthen Environmental Policies and Hygiene Practices}

There is a need to strengthen environmental hygiene practices in all levels of learning. Responsiveness of the society starts when learners are educated in the schools. Creating awareness to the students about societal issues, especially of health concerns challenges the universities. The COVID-19 pandemic has posited school closures globally, so, environmental hygiene should be a priority in schools to prevent the transmission and outbreak of infectious diseases (Lee et al., 2003) in the future. Students should also be taught to gain knowledge and behaviour practices on the prevention of infectious diseases. The students can be given health management tools that can let them practice protocols until good hygiene becomes a school culture. To achieve the goal, the university needs to craft a policy to control the transmission root of the virus (Lee et al., 2003). Thereby, effective health and environmental policies should be crafted anchored on a sustainable environmental framework of a university.

\section{Incorporate an Online Mental Health and Medical Services}

For quality indicators of a higher education enterprise, there should be a set of values and principles that accounts for the expressed needs of its stakeholders, particularly the students (Ludeman, Osfield, Hidalgo, Oste, \& Wang, 2009).

Schools need to strengthen its medical services and student support services so that constant monitoring and implementation of health practices are followed within the vicinity and beyond the academe. Due to global trends of the pandemic, higher education needs to prioritize the academic, career counselling, and even the medical services and programs that should be accessible to the students in the university and even through online means. In fact, mental health needs in the universities have gained significant attention (McBride, Van Orman, Wera, \& Leino, 2010) due to the increasing number of mental disorders among college students (Blanco et al., 2008; Dalky \& Gharaibeh, 2018; Hinderaker, 2013; Hunt \& Eisenberg, 2010; Pedrelli, Nyer, Yeung, Zulauf, \& Wilens, 2015).

Free virtual services such as medical counselling, mental health teleconferencing, and other related online health services from medical staff representatives and professional health experts such as psychologists and guidance counselors should be readily accessible for the students even outside the centers (Hinderaker, 2013). A study (McBride, Van Orman, Wera, \& Leino, 2010) reported having the highest offerings on primary care services (98\%) along with health promotion (90\%) under a range of health services. The online care services would expedite the assessments and provide adequate services for better outcomes of the students to seek treatment and engagement (Pedrelli et al., 2015).

Furthermore, for a basic understanding of COVID-19, higher education institutions should also formulate a management protocol and flow chart focused on campus medical services to serve as public health awareness measures (Lee et al., 2003). The information should map the symptoms, risks, and management guidelines to seek for primary care services contextualized in the school setting to prevent the direct transmission of the virus. Other health-related services such as mental health services also need development of its management flow chart and promotion of this agenda because mental health is part of the wellbeing that is connected to the academic success of the students (Dalky, \& Gharaibeh, 2018; Hunt \& Eisenberg, 2010). Institutions can advance 
on promoting health services for the students especially when done through online dissemination since they are active in their social media accounts.

\section{Migrate Courses, Align Curriculum Competencies, and Scale up Teachers' Training for Online Learning Instruction}

Due to the COVID-19 pandemic, higher education intuitions the world over are shifting to online learning or distance education programs. The advantage is it can allow for the students to learn at their convenience since it is needless to attend training centers and universities (Knibel, 2001). This large shift to online instruction does not need for the face to face interaction between teachers and the students together with their classmates so there is prevention and control over the spread of the virus. Higher education institutions in the Philippines thereby should prepare the courses for online transfer since another epidemic can breakout in the future. That indicates aligning the competencies that students should learn in the subject courses in an online format. By doing this, universities can expedite its response for continuous learning of the stakeholders.

Although this online delivery can present barriers to the teachers since they need to acquire online-driven competencies in planning, implementing, and assessing the performance of their students, providing teachers with adequate training courses can assist them to effectively implement the courses through electronic delivery. There are various devices available with innovative tools for the teachers to access to promote learning for the students with diverse educational needs. The technology devices, design of the program, choices of instructors, responsive curriculum, and supportive stakeholders are necessary and significant for the successful delivery of the lessons in an online environment (Barr \& Miller, 2013). In that case, this brings an opportunity for higher education institutions to scale up the training of the teachers for online learning instruction. The training for the teachers can improve student learning in educational programming for the instructors to facilitate the goals aligned to the learning goals of higher education institutions (Ludeman et al., 2009).

\section{Strengthen Research Efforts, Data Monitoring, and Evidence-Based Practices}

Institutions of higher education are expected to demonstrate responsiveness to the stakeholders. The expectations are higher because of the bars that government entities, accreditation agencies, and other stakeholders are setting for the performance of higher level institutions (Ludeman et al., 2009). Higher education needs to demonstrate effectiveness and efficiency in the educational administration because the stakeholders demand evidence from institutions to support the claims of excellence and effectiveness. Other than that, these are changing times globally, and even the pandemic has affected the way that educational systems should function that a great deal of evidences are needed to determine how higher education institutions should respond to the educational, economic, and employment crises. There is an even greater need to produce research reports on the impact of COVID-19 pandemic to the educational system in the country.

Higher education institutions need to seize these opportunities to strengthen data monitoring, documentation and evidencebased practices of the services and programs that are offered to the students. There have been numerous innovative programs of higher learning but these innovations are not assessed rigorously (Hunt \& Eisenberg, 2010). For example, little research has been published referring to the counseling center utilizations in the universities (Hinderaker, 2013). Even in the Philippines, there is a need for more scientific data on the provision of mental health services in college campuses nationally and locally. Hence, research, evaluation, and strategic planning are central to student success. These research efforts can meet the challenges in the future to provide information that are crucial for transparency and accountability (Ludeman et al., 2009). The faculty, researchers, and professionals of higher education need to engage and strengthen the efforts in research, evaluation, and strategic planning to document best processes, increase evidence-based practices, and improve student learning in higher education in the Philippines even amidst the COVID-19 pandemic or possible spread of other viruses in the coming years.

\section{IMPLICATIONS FOR FURTHER STUDIES}

The paper highlights pedagogical and policy implications. To effectively respond to the threat of the pandemic, universities need to reassess the curricular interventions to gear for readiness towards online learning. Likewise, campus medical health representatives can develop health management protocols and tools to ensure that stakeholders follow environmental health practices even outside the academe. Aside from the academic implications, this paper also presents policy implications to craft environmental policies that can strengthen the health management systems in the university. This article can also serve as reference for future studies relative to the effects of COVID-19 to the performance of the educational system. On the other hand, there remains numerous gaps in the scientific community as to the impact of COVID-19 to higher education. Future studies should evaluate the impact of the COVID-19 pandemic to the educational system and gather scientific evidences on how the educational institutions can effectively respond to another future virus outbreak.

\section{CONCLUSION}

Higher education worldwide is affected due to the COVID-19 pandemic that thousands of school closures followed in a very limited span of time to enforce social distancing measures. Educational institutions particularly in the Philippines, are presented with surmounting challenges in its system of planning, implementation, and assessment. On a light note, however, the global pandemic opened up opportunities to the country to upgrade its educational mode of delivery and transfer its attention to emerging technologies. Higher education institutions thereby need to seize the opportunity to strengthen its evidence-based 
practices, provide accessible mental health-related services, and make the curriculum responsive to the needs of the changing times.

\section{REFERENCES}

Abdulamir, A. S., \& Hafidh, R. R. (2020). The Possible Immunological Pathways for the Variable Immunopathogenesis of COVID-19 Infections among Healthy Adults, Elderly and Children. Electronic Journal of General Medicine, 17(4), em202. https://doi.org/10.29333/ejgm/7850

Amin, A., Mahadi, Z., Ibrahim, R., Yaacob, M., \& Nasir, Z. (2012). The effectiveness of the 'environment \& health' course in increasing students' awareness \& knowledge on environmental health issues. Procedia Social and Behavioral Sciences. https://doi.org/10.1016/j.sbspro.2012.09.248

Bao W. (2020) COVID-19 and online teaching in higher education: A case study of Peking University. Hum Behav \& Emerg Tech. 2020, 1-3. https://doi.org/10.1002/hbe2.191

Barr, B., \& Miller, S. (2013). Higher Education: The Online Teaching and Learning Experience. Retrieved from https://www.google.com/url?sa=t\&source=web\&rct=j\&url=https://files.eric.ed.gov/fulltext/ED543912.pdf\&ved=2ahUKEwiS3t KI2N3oAhUm-2EKHfNoCR8QFjABegQIAxAB\&usg=AOvVaw10Sal8UOXPU8DFS3h782jT

Bender, L. (2020). Key Messages and Actions for COVID-19 Prevention and Control in Schools. Retrieved from https://www.unicef.org/romania/documents/key-messages-and-actions-covid-19-prevention-and-control-schools

Blanco C, Okuda, M. Wright, C., Hasin, D.S., Grant, B.F., Liu, S.M., \& Olfson, M. (2008). Mental health of college students and their non-college-attending peers: Results from the National Epidemiologic Study on Alcohol and Related Conditions. Arch Gen Psychiatry, 65(12), 1429-1437. https://doi.org/10.1001/archpsyc.65.12.1429

Dalky, H. F., \& Gharaibeh, A. (2018). Depression, anxiety, and stress among college students in Jordan and their need for mental health services. Nurs Forum. pp. 1-8. https://doi.org/10.1111/nuf.12316

Department of Health (DOH, 2020). Updates on Novel Coronavirus Disease. Retrieved from http://www.doh.gov.ph/2019-nCoV

Fox, R. (2007). SARS epidemic: Teachers' experiences using ICTs. Retrieved from https://www.google.com/url?sa=t\&source=web\& rct=j\&url=https://www.ascilite.org/conferences/perth04/procs/pdf/fox.pdf\&ved=2ahUKEwi83ljD2N3oAhWm-GEKHRgcCCUQ FjABegQIAhAB\&usg=AOvVaw1pZFXsa8vwVtg_19X7YwtN

Gondauri, D., Mikautadze, E., \& Batiashvili, M. (2020). Research on COVID-19 Virus Spreading Statistics based on the Examples of the Cases from Different Countries. Electronic Journal of General Medicine, 17(4), em209. https://doi.org/10.29333/ejgm/7869

Hinderaker, D. (2013). College Student Mental Health and Use of Counseling Center Services. Retrieved from Sophia, the St. Catherine University repository website: https://sophia.stkate.edu/msw_papers/190

Holshue, M. L., DeBolt, C., Lindquist, S., Lofy, K. H., Wiesman, J., et al. (2020) First case of 2019 novel coronavirus in the United States. N Engl J Med [epub ahead of print 31 Jan 2020] in press. https://doi.org/10.1056/NEJMoa2001191

Hunt, J., \& Eisenberg, D. (2009). Mental Health Problems and Help-Seeking Behavior among College Students. Journal of Adolescent Health, 46(2010), 3-10. https://doi.org/10.1016/j.jadohealth.2009.08.008

Keselman, A., Levin, D., Kramer, J., Matzkin, M., \& Dutcher, G. (2011). Educating Young People about Environmental Health for Informed Social Action. Umw Gesundh Online, 4, 1-8. Retrieved from https://www.ncbi.nlm.nih.gov/pubmed/24383062

Knibel, E. (2001). The Use and Effect of Distance Education in Healthcare: What Do We Know? Bethesda, MD: Published for the U.S. Agency for International Development (USAID) by the Quality Assurance Project. Operations Research Issue Paper, 2(2). Retrieved from https://www.semanticscholar.org/paper/The-Use-and-Effect-of-Distance-Education-in-\%3A-WhatKnebel/cda9b3bd188a9541aed3e670ec8ba6a6f1516df7\#citing-papers

Lee, A., Cheng, F. F. K., Yuen, H., et al. (2003). How would schools step up public health measures to control spread of SARS? Journal of Epidemiology \& Community Health, 57, 945-949. https://doi.org/10.1136/jech.57.12.945

Ludeman, R., Osfield, K., Hidalgo, E. I., Oste, D., \& Wang, H. (2009). Student Affairs and Services in Higher Education: Global Foundations, Issues and Best Practices. United Nations Educational, Scientific and Cultural Organization, France. Retrieved from https://unesdoc.unesco.org/ark:/48223/pf0000183221

McBride, D., Van Orman, S., Wera, C., \& Leino, V. (2010). ACHA Benchmarking Committee Report: 2010 Survey on the Utilization of Student Health Services. American College Health Association Benchmarking Committee. Retrieved from https://www.google.com/url?sa=t\&source=web\&rct=j\&url=https://www.acha.org/documents/resources/survey_data/bench marking/ACHA_Benchmarking_Report_2010_Utilization_Survey.pdf\&ved=2ahUKEwi65trv2N3oAhXLc94KHadxDAUQFjADegQ IBhAC\&usg=AOvVaw3ErCkLGrBYwvd3LHpC9dD5\&cshid=1586516116329

Meng, L., Hua, F., \& Bian, Z. (2020). Coronavirus Disease 2019 (COVID-19): Emerging and Future Challenges for Dental and Oral Medicine. Journal of Dental Research. https://doi.org/10.1177/0022034520914246

Pedrelli, P., Nyer, M., Yeung, A., Zulauf, C., \& Wilens, T. (2015). College Students: Mental Health Problems and Treatment Considerations. Acad Psychiatry, 39(5), 503-511. https://doi.org/10.1007/s40596-014-0205-9

Sintema, E. J. (2020). Effect of COVID-19 on the Performance of Grade 12 Students: Implications for STEM Education. Eurasia Journal of Mathematics, Science and Technology Education, 16(7), em1851. https://doi.org/10.29333/ejmste/7893 
Türkoglu, B. (2019). Opinions of Preschool Teachers and Pre-Service Teachers on Environmental Education and Environmental Awareness for Sustainable Development in the Preschool Period. Sustainability, 11(4925), 1-35. https://doi.org/10.3390/su11184925

UNESCO (2020). Global Monitoring of School Closures caused by COVID-19. Retrieved from https://en.unesco.org/covid19/educationresponse

Usak, M., Masalimova, R. A., Cherdymova, I. E., \& Shaidullina, R. A. (2020). New playmaker in science education: Covid-19. Journal of Baltic Science Education, 19(2), 180-185. https://dx.doi.org/10.33225/jbse/20.19.180

Yan Z. (2020). Unprecedented pandemic, unprecedented shift, and unprecedented opportunity. Hum Behav \& Emerg Tech, 2020, 1-3. https://doi.org/10.1002/hbe2.192 